\title{
Investigating Students' Perspectives of Foreign Language Distance Education Curriculum According to Some Variables
}

\author{
Ali Orhan ${ }^{1}$, Şule Çeviker $A y^{2}$ \\ ${ }^{1}$ School of Foreign Languages, Bülent Ecevit University, Zonguldak, Turkey \\ ${ }^{2}$ Faculty of Education, Düzce University, Düzce, Turkey \\ Correspondence: Ali Orhan, School of Foreign Languages, Bülent Ecevit University, Zonguldak, Turkey.
}

Received: February 27, 2017

Accepted: March 10, 2017 Online Published: March 20, 2017

doi:10.11114/jets.v5i4.2246

URL: https://doi.org/10.11114/jets.v5i4.2246

\begin{abstract}
This study was carried out to investigate the students' satisfaction levels of foreign language distance education curriculum in a state university according to some variables. In the study, it was aimed to answer these questions: "What are the students' opinions about the distance education curriculum of Foreign Language I course and do their opinions differ according to some variables?" Context, Input, Process and Production (CIPP) evaluation model was used as a curriculum evaluation framework and descriptive survey model, one of the quantitative research models, was used in this study. Sample of the study is composed of 715 freshman students who are enrolled in the faculties and colleges of university and took the Foreign Language I course in 2015-2016 academic year. 5-point likert scale was developed by the researchers to collect data. Independent samples t-test and one-way Anova was used to analyze the collected data with the help of SPSS 20. As a result of the study, it was found out that the students' responses are gathered around the "I neither agree nor disagree" option. The component which has the highest satisfaction level is process component of curriculum and product component has the least satisfaction level. Opinions of the students about curriculum don't differ significantly according to their gender and age. However, their opinions differ significantly according to their education type, daily internet connection hours and final grades. Also the students, who have personal computer and have attended another distance education, have more positive opinions than the students who don't have computer and any distance education experience.
\end{abstract}

Keywords: distance education, curriculum evaluation, CIPP evaluation model, English language curriculum

\section{Introduction}

Significant progress in different kind of fields, such as transportation, energy and industry, after the end of the Second World War in 1945s, has changed the world into industrial society (Webster, 2001). In addition to this progress, discovery of internet in 1980s and proliferation of it in years after 1990 has turned the industrial society into information society (Bell, 1999). So, while the era before the proliferation of internet is called industrial society, after discovery and usage of internet, information age has started.

In $21^{\text {st }}$ century in which technology has significantly progressed, reaching, spreading and learning of knowledge are really easy. Therefore, this progress has affected education too. With information age, the world witnessed information explosion and this information can go around the world without any geographical boundaries (Demir, 2014). Global communication network, which has appeared in the current century, gives people chance of communicating each other in written, verbal and visual ways. Also, this communication network gives educators chance of providing global distance education (Işman, 2008). So, because of this progress which is really fast and can affect education, people are dragged into lives which are full of information, curriculums are revised and investment in education increases. In this information age, researchers state that virtual universities will become popular and education will be implemented in global network thanks to the development in technology (Çallı et al., 2001).

Besides this development in technology, in today's world number of the students, who participate in education, has increased in parallel with the population growth of the countries. However, in spite of this increase in the number of students, some of the countries can't increase their qualified instructors (Karakaya and Aksoy, 2005). Despite this, while people want to have education in different places and at different times, institutions want to provide fast and economical in-service training to their employees. Many reasons like these force educators to discover different education models. 
Distance education is a model which is presented by people to fulfill this education need by means of technology.

According to Simonson (2002), distance education is an institutional activity in which learner and teacher are in different places and the communication between them is provided via technology. On the other hand, Işman says that distance education is one of the different teaching-learning ways and is a system in which teacher and learner, who are in different places, interact each other by means of technology (Yadigar, 2010). Distance education is a kind of education that is provided by printed materials and technological platforms, which make possible two way communication between teacher and learner. Some of the main differences between traditional and distance education are freedom of place and time, flexibility of course time, reaching large masses, cost and review.

Distance education has gone through different stages until today and it is carried out in many places of the world nowadays (Yadigar, 2010). Today, distance education is carried out online by means of virtual classes or universities which are created with the help of internet technologies (Moore and Kearsley, 2005). Many universities have increased the number of distance education curriculums swiftly. These curriculums are such as to take place of face-to-face education or to support face-to-face education. Thus, it is needed that these learning-teaching activities, carried out by distance education, should be monitored and improved. So this study was carried out to serve this purpose. Its aim is to investigate students' opinions about the foreign language distance education curriculum in a state university, which is located in Black Sea Region of Turkey. Context, Input, Process and Production (CIPP) evaluation model was used as a curriculum evaluation framework. The scale, which was used to collect data, was developed according to principles of CIPP evaluation model and the data was analyzed according to CIPP's four components. So in line with this purpose, the problem statement of the study is that "What are the students' opinions about the distance education curriculum of Foreign Language I course; and do their opinions differ according to different variables?"

In accordance with this problem statement, researchers seek answers to these questions below:

1. What are the students' opinions about the distance education curriculum of Foreign Language I course?

2. Do students' opinions about the distance education curriculum of Foreign Language I course differ according to some variables?

The Foreign Language I course is taught to the students of first class during the fall term at the all departments of the university. Also, this lesson has been performed through distance education method since 2014-2015 academic year. The aim of the course is to improve necessary skills and strategies by didactic activities and enhance their grammar knowledge by teaching correct linguistic and grammatical structures. Course includes the usage of four skills, "speaking", "reading", "writing" and "listening" together to enhance the learning process. In addition to that, another aim of the course is to teach specific vocabularies and to provide the correct usage of them by teaching grammatical characteristics of vocabularies such as their correct usage and affixes. Strategy of learning vocabulary, strategy of memorization, strategy of usage of them when needed, strategy of guessing the meaning of unknown vocabularies in texts are some of the other strategies which will be acquired during the course.

During the Foreign Language I course, which has been performed through asynchronous distance education method, students have to keep up with course materials, videos and exercises which are uploaded to system by teacher every week. The teacher, who is responsible for the course, has to check whether the students complete course materials or not. Within the scope of distance education, no other synchronous course is carried out. Students can consult with the responsible instructor of the course face to face or online by using the distance education system during office hours. Compulsory attendance is followed by checking whether the students complete weekly course materials and exercises or not. Exams are prepared by School of Foreign Languages and carried out in classes by instructor and under the responsibility of relevant faculty or college.

\section{Method}

\subsection{Model of the Study}

In this study, which aims to investigate students' opinions about the foreign language distance education curriculum in a state university according to some variables, descriptive survey model was used.

\subsection{Universe and Sample}

In this study, the universe is all students ( $\mathrm{N}$ : 8664), who have taken Foreign Language I course in Fall term in 2015-2016 academic year. Sampling was used in this study because of the size of the population. The number of students in sample, created by stratified sampling method, and their faculties and colleges can be seen in Table 1 . 
Table 1. The number and percentage of students in universe and sample according to their faculties/colleges on main and outer campuses

\begin{tabular}{lcccc}
\hline & \multicolumn{2}{c}{ Universe } & \multicolumn{2}{c}{ Sample } \\
\hline Faculty/College & f & $\mathbf{\%}$ & f & $\mathbf{\%}$ \\
\hline Faculty of Engineering & 866 & 9,86 & 51 & 7,1 \\
Faculty of Economics and Administrative Sciences & 970 & 11,05 & 60 & 8,4 \\
Faculty of Arts and Sciences & 377 & 4,29 & 42 & 5,9 \\
College of Physical Education and Sports & 42 & 0,48 & 22 & 3,1 \\
Faculty of Theology & 228 & 2,60 & 24 & 3,4 \\
Ahmet Erdoğan Health Services Vocational College & 621 & 7,07 & 66 & 9,2 \\
Faculty of Dentistry & 58 & 0,66 & 6 & 0,8 \\
Faculty of Medicine & 96 & 1,09 & 10 & 1,4 \\
Zonguldak Health College & 433 & 4,93 & 54 & 7,6 \\
Zonguldak Vocational College of Higher Education & 1070 & 12,19 & 63 & 8,8 \\
State Conservatory & 35 & 0,40 & 9 & 1,3 \\
Faculty of Fine Arts & 38 & 0,43 & 8 & 1,1 \\
\hline Main Campuses Subtotal & $\mathbf{4 8 3 4}$ & $\mathbf{5 5 , 0 6}$ & $\mathbf{4 1 5}$ & $\mathbf{5 8}$ \\
\hline Çaycuma Vocational College of Higher Education & 805 & 9,17 & 61 & 8,5 \\
Devrek Vocational College of Higher Education & 479 & 5,45 & 44 & 6,2 \\
Gökçebey Vocational College of Higher Education & 169 & 1,92 & 23 & 3,2 \\
Alaplı Vocational College of Higher Education & 1412 & 16,08 & 90 & 12,6 \\
Ereğli Faculty of Education & 742 & 8,45 & 62 & 8,7 \\
Kdz. Ereğli Vocational College of Higher Education & 280 & 3.19 & 14 & 2 \\
Faculty of Maritime & 53 & 0,60 & 6 & 0,8 \\
College of Maritime Management and Administration & 07 & 0,08 & 0 & 0 \\
\hline Outer Campuses Subtotal & $\mathbf{3 9 4 7}$ & $\mathbf{4 4 , 9 4}$ & $\mathbf{3 0 0}$ & $\mathbf{4 2}$ \\
\hline Total & $\mathbf{8 7 8 1}$ & $\mathbf{1 0 0}$ & $\mathbf{7 1 5}$ & $\mathbf{1 0 0}$ \\
\hline
\end{tabular}

After sampling according to their representation rates in universe, 415 students (\%58) from faculties/colleges on main campuses and 300 students (\%42) from faculties/colleges on outer campuses are included in this study. So the sample of this study was composed of 715 students. Demographic features of these students can be seen in Table 2.

As it can be seen in Table 2, 472 of students who involved in the study are female $(\% 66,3)$ and 241 of them are male $(\% 33,7)$. Most of the students' ages are between 18 and $21(\% 78,5)$ and \%18,9 of them are 22-25 years old. When students' type of education analyzed, it can be seen that while 557 students are enrolled in daytime education $(\% 77,9)$, 158 students are enrolled in evening education $(\% 22,1)$. Most of the students have personal computer $(\% 69,1)$. Also, most of the students state that they haven't attended another distance education training (\%79,5). 337 of students spend 0-2 hours (\%47,1), 264 of them spend 3-5 hours (\%36,9), 77 of them spend 6-8 hours (\%10,8), 16 of them spend 9-11 hours $(\% 2,2)$ and 21 of them spend more than 12 hours on internet. Students' final grades of Foreign Language I are mostly between of 45-57 (\%32) and then respectively between 58-72 (\%29,5), 0-44 between (\%23,4), 73-86 between $(\% 11,6)$ and $87-100$ between $(\% 3,5)$. 
Table 2. The number and percentage of students according to their demographic features

\begin{tabular}{|c|c|c|c|c|}
\hline Demographic Features & & $\mathbf{n}$ & $\%$ & Total \\
\hline \multirow{2}{*}{ Gender } & Female & 474 & 66,3 & \multirow{2}{*}{715} \\
\hline & Male & 241 & 33,7 & \\
\hline \multirow{9}{*}{ Age } & 18 & 70 & 9,8 & \multirow{9}{*}{715} \\
\hline & 19 & 157 & 22 & \\
\hline & 20 & 196 & 27,4 & \\
\hline & 21 & 138 & 19,3 & \\
\hline & 22 & 64 & 9 & \\
\hline & 23 & 38 & 5,3 & \\
\hline & 24 & 23 & 3,2 & \\
\hline & 25 & 10 & 1,4 & \\
\hline & $26+$ & 19 & 2,7 & \\
\hline \multirow{2}{*}{ Type of Education } & Daytime Education & 557 & 77,9 & \multirow{2}{*}{715} \\
\hline & Evening Education & 158 & 22,1 & \\
\hline \multirow{2}{*}{ Personal Computer } & Have & 494 & 69,1 & \multirow{2}{*}{715} \\
\hline & Do not have & 221 & 30,9 & \\
\hline \multirow{2}{*}{ Attended Another Distance Education } & Yes & 182 & 25,5 & \multirow{2}{*}{715} \\
\hline & No & 533 & 74,5 & \\
\hline \multirow{5}{*}{ Daily Internet Connection Hours } & $0-2$ & 337 & 47,1 & \multirow{5}{*}{715} \\
\hline & $3-5$ & 264 & 36,9 & \\
\hline & $6-8$ & 77 & 10,8 & \\
\hline & $9-11$ & 16 & 2,2 & \\
\hline & $12+$ & 21 & 2,9 & \\
\hline \multirow{5}{*}{ Final Grade of Foreign Language I } & $0-44$ & 167 & 23,4 & \multirow{5}{*}{715} \\
\hline & $45-57$ & 229 & 32 & \\
\hline & $58-72$ & 211 & 29,5 & \\
\hline & $73-86$ & 83 & 11,6 & \\
\hline & $87-100$ & 25 & 3,5 & \\
\hline
\end{tabular}

\subsection{Data Collection}

Data was collected by a scale, developed by the researchers, in this study. After permission which is necessary to practice the scale in faculties and colleges of the university, an action plan was made by negotiating with the academic members who work in faculties and colleges. After the voluntary students were informed about the scale and study, the scale was practiced according to plan in faculties and colleges by the researcher.

\subsection{Data Collection Instrument}

The scale was developed in the frame of Stufflebeam's CIPP evaluation model principles. In the first part of the scale, there are questions such as age, gender etc. to obtain data about students' demographic features. In the second part, there are statements to determine students' opinions about the four components of CIPP evaluation model. The questions of the scale are in the form of five-point likert scale: (1) I definitely disagree, (2) I disagree, (3) I neither agree nor disagree, (4) I agree, (5) I completely agree).

To examine the content validity, the initial version of scale was sent to 3 faculty members. Some of the statements were changed according to their opinions. Then to provide construct validity, the scale was given to 163 students and factor analysis was conducted. According to the results of factor analysis, it was found out that the total variance explained was $\% 75,40$ and the scale was collected in twenty factors whose eigenvalues were greater than one, yet these factors couldn't be given any meaningful names. Also while preparing the statements for the scale, the statements were considered in four components, that is, four factors. These components consisted of context, input, process and product evaluation. As Büyüköztürk (2002) emphasizes, in a condition in which the same item has high factor loading in two different factors, the difference must be at least 0,10 , the factor loadings of the items must be at least 0,45 and the items must be grouped under a single factor. So problematic statements whose factor loadings were under 0,45 and collected 
under two different factors with high factor loadings were removed from the scale. After removing these statements, the scale was analyzed in four factors and an exploratory factor analysis with varimax rotation was conducted to examine construct validity of the scale. So the total variance explained of the scale, which has four factors, is $\% 62,69(\% 45,05$ by the first factor, $\% 7,18$ by the second factor, $\% 6,04$ by the third factor and $\% 4,45$ by the fourth factor).

Examining whether each factor was measuring a single idea and whether the items that made up the factors were internally consistent, internal reliability data was obtained through Cronbach's alpha coefficient among the 4 factors. The reliability coefficients of four components ranged from 0,87 to 0,94 and the reliability coefficient of the whole scale was found to be 0,96 . Also the values of item-total correlations of the items ranged from 0,50 to 0,76 . Briefly, the data was collected by the valid and reliable scale which has been developed by researchers.

\subsection{Analysis of Data}

The data obtained via the scale was transferred into the computer and the calculations were made using SPSS (Statistical Package for Social Sciences) 20 program as statistical techniques. To interpret the students' opinions about distance education curriculum, the averages, frequency and standard deviation of their responses were found. As the scale was designed as a five-point likert scale, the means of the students' responses were used and the point intervals were as follows; $1-1.79$ as "I definitely disagree", 1.80-2.59 as "I disagree", 2.60-3.39 as "I neither agree nor disagree", $3.40-4.19$ as "I agree" and $4.20-5$ as "I completely agree". These intervals were calculated by the formula of $5-1=4$ and $4 / 5=0.80$. In order to find the answers to the second problem of the research, the students' responses collected with the scale were analyzed using the technique of independent samples t-test and one-way Anova; and to determine which means differ, Tamhane's T2 and Tukey tests were used.

\section{Results}

\subsection{Findings on the Opinions of the Students about Distance Education Curriculum of Foreign Language I Course}

In the first question of the research, it was aimed to find out the opinions of students about distance education curriculum of Foreign Language I course as a whole and their opinions on context, input, process and product components of the curriculum. Therefore, the average of the students' responses and standard deviation values to the curriculum as a whole and the context, input, process and product components of curriculum are calculated and given in Table 3 .

Table 3. Averages and standard deviation values of student responses to different components and total scale

\begin{tabular}{lcc}
\hline & $\mathrm{X}$ & $\mathbf{s s}$ \\
\hline Context Evaluation & 2,79 & 0,96 \\
Input Evaluation & 2,77 & 0,90 \\
Process Evaluation & 3,01 & 0,88 \\
Product Evaluation & 2,76 & 0,96 \\
Total Scale & 2,83 & 0,82 \\
\hline
\end{tabular}

When Table 3 is examined, it can be seen that students' responses are gathered around "I neither agree nor disagree" option for all components. When the average responses of the four components of the curriculum are examined, it can be seen that product component has the lowest average $(\bar{X}: 2,76)$. The product component is followed by the input $(\overline{\mathrm{X}}$ : $2,77)$ and context $(\bar{X}: 2,79)$ components respectively. The process component has the highest average of student opinions $(\bar{X}: 3,01)$. The fact that students have relatively positive opinions about the process component $(\bar{X}: 3,01)$ suggests that students use the available resources and materials efficiently and that they liked the instructors' performance relatively. When the average of students' responses about the total scale is examined, it is seen that their responses are gathered around "I neither agree nor disagree" option ( $\overline{\mathrm{X}}: 2,83)$.

To thoroughly examine the students' opinions about different components of the curriculum, the averages and standard deviation values of the students' responses to the items were calculated and given in Table 4.

When Table 4 is examined, it is seen that students' responses to "The aims of the curriculum are in harmony with the needs of the students" and "The aims of the curriculum are in harmony with the expectations of the students" items are gathered around "I neither agree nor disagree" ( $\overline{\mathrm{X}}: 2,85, \overline{\mathrm{X}}: 2,77$ ). Therefore, it can be said that the students think that curriculum is in harmony with their needs and expectations moderately. Besides that, the most common response to "The curriculum is suitable for students' English language levels" item is "I neither agree nor disagree" ( $\bar{X}: 2.93$ ). However, this is also the item which has the highest average in context component $(\overline{\mathrm{X}}: 2.93)$.

The averages of the students' responses to "The duration of the curriculum is sufficient to achieve the objectives of the curriculum" and "The curriculum is complementary to the other courses" are 2.88 and 2.76 . Therefore, it is possible to 
say that the opinions of students about these items are at the level of "I neither agree nor disagree".

Table 4. Averages and standard deviation values of the students' responses to the items in context component of the curriculum

\begin{tabular}{lcc}
\hline Context Evaluation & $\bar{X}$ & ss \\
\hline 1. The aims of the curriculum are in harmony with the needs of the students. & 2,85 & 1,20 \\
2. The aims of the curriculum are in harmony with the expectations of the students. & 2,77 & 1,16 \\
3. The curriculum is suitable for students' English language levels & 2,93 & 1,19 \\
4. The duration of the curriculum is sufficient to achieve the objectives of curriculum. & 2,88 & 1,16 \\
5. The curriculum is complementary to the other courses & 2,76 & 1,18 \\
6. Distance learning English classes can improve English language knowledge. & 2,55 & 1,27 \\
Total & 2,79 & 0,96 \\
\hline
\end{tabular}

The only item that students do not agree in context evaluation component is "Distance learning English classes improve English language knowledge" ( $\overline{\mathrm{X}}: 2,55)$. Therefore, while the averages of the students' responses about the curriculum's harmony with their needs and expectations, its suitability to their language levels, its duration and relation to other courses are "I neither agree nor disagree", the average of their responses to "Distance learning English classes can improve English language knowledge" item is "I do not agree". Averages and standard deviation values of students' responses to the items in the input component of the curriculum are given in Table 5.

Table 5. Averages and standard deviation values of the students' responses to the items in input component of the curriculum

\begin{tabular}{lcc}
\hline Input Evaluation & $\overline{\mathrm{X}}$ & ss \\
\hline $\begin{array}{l}\text { 7. The portal provides adequate resources for English listening skill that is intended to be } \\
\text { developed. }\end{array}$ & 2,65 & 1,17 \\
$\begin{array}{l}\text { 8. The portal provides adequate resources for English writing skill that is intended to be } \\
\text { developed. }\end{array}$ & 2,65 & 1,17 \\
$\begin{array}{l}\text { 9. The portal provides adequate resources for English speaking skill that is intended to be } \\
\text { developed. }\end{array}$ & 2,55 & 1,17 \\
$\begin{array}{l}\text { 10. The portal provides adequate resources for English reading skill that is intended to be } \\
\text { developed. }\end{array}$ & 2,66 & 1,19 \\
$\begin{array}{l}\text { 11. The portal provides adequate resources for English grammar that is intended to be } \\
\text { developed. }\end{array}$ & 2,74 & 1,21 \\
$\begin{array}{l}\text { 12. The learning resources / materials used on the portal are of high quality. } \\
\text { 13. The course content offered is qualified. }\end{array}$ & $\begin{array}{l}2,80 \\
\text { 14. The number of tests in the portal is sufficient. }\end{array}$ & 1,10 \\
\hline Total & 3,03 & 1,13 \\
\hline
\end{tabular}

When Table 5 is examined, it can be seen that the averages of the students' responses to 7 out of 8 items in the input component is "I neither agree nor disagree" and the most positive opinion is about the quality of the course content ( $\mathrm{X}$ : $3,04)$; and it is followed by the item which is about number of tests $(\bar{X}: 3,03)$. The item, which has the most negative opinion, is about whether the students are given enough material related to speaking skill ( $\overline{\mathrm{X}}: 2,55)$. Therefore, while students agree moderately with the idea that they are given enough resources about listening, writing, reading and grammar $(\bar{X}: 2.65, \bar{X}: 2.65, \bar{X}: 2.66, \bar{X}: 2.74)$, they don't agree with the idea that they are given enough resources about speaking $(\bar{X}: 2,55)$. In addition, students think that they are given the most resources about grammar $(\bar{X}: 2.74)$, and it is followed by reading ( $\bar{X}: 2.66)$.

The answers given by the students about "The learning resources / materials used on the portal are of high quality" are gathered around "I neither agree nor disagree" ( $\overline{\mathrm{X}}: 2.80)$. Therefore, although average of the students' responses about the quality of materials and resources is "I neither agree nor disagree", it is greater than the average of their responses about the number of materials and resources.

In addition, the average of the students' responses to "The course content offered is qualified" is 3.04. Therefore, even though the answers given by the students about the quality of the course content are gathered around the "I neither agree nor disagree", they are not too far away from "I agree" option ( $\bar{X}: 3,04)$. Moreover, the item with the highest average among the items in the input component is also this item. Therefore, the opinions of the students on the content of the course are much more positive than the opinions of the students about the number and quality of the materials and resources which are offered during the course.

Most of the students gave the answer "I neither agree nor disagree" to "The number of tests in the portal is sufficient" 
$(\bar{X}: 3,03)$. So, although opinions on the number of tests presented on the portal are at the moderate level, they are close to positive. The fact that the average of the responses to this item is higher than the average of the responses to the items related to the materials and resources can be interpreted as the students want something else other than tests as material and resource. Averages and standard deviation values of students' responses to the items in the process component of the curriculum were calculated and given in Table 6 .

Table 6. Averages and standard deviation values of the students' responses to the items in process component of the curriculum

\begin{tabular}{lcc}
\hline Process Evaluation & $\bar{X}$ & ss \\
\hline 15. Questions can be asked easily to the instructor of the course. & 3,07 & 1,21 \\
16. Instructors are trying to find easy ways to teach the subject. & 2,91 & 1,15 \\
17. Instructors are implementing the curriculum in accordance with its purpose. & 3,05 & 1,15 \\
18. Instructors are using appropriate teaching methods to teach the subject. & 3,04 & 1,13 \\
$\begin{array}{l}\text { 19. Instructors are using materials effectively. } \\
\text { 20. They try to solve the problem if any troubles appear during the courses. }\end{array}$ & 2,93 & 1,15 \\
21. The course materials and tests offered on the portal are used in a way to strengthen the & 2,97 & 1,16 \\
subject. & 2,98 & 1,15 \\
22. Exams are hold without any problems. & 3,07 & 1,20 \\
23. The instructors teach the subject clearly and explicitly during the videos presented on the & 3,04 & 1,16 \\
portal. & 3,01 & 0,88 \\
\hline Total
\end{tabular}

The answers given by the students to the item "Questions can be asked easily to the instructor of the course" are gathered around the "I neither agree nor disagree" option ( $\bar{X}: 3,07)$. However, it can be said that they are not far away from the "I agree" option because it is above 3. Therefore, It is possible to say that students can communicate with the instructors and ask their questions when they need.

In addition, the answers, given to the $16,17,18,19$ and 23 items, which are about the instructors' quality of lecturing in the course videos, range from 2,91 to 3,05 . Therefore, the answers given by the students to the items about instructors' lecturing the course and the effective use of materials by the instructors are similarly gathered around the "I neither agree nor disagree" option. So students have an opinion close to positive about the instructors' performance.

The average of the students' responses to the item "They try to solve the problem if any troubles appear during the courses" is 2,97 . Therefore, the students think moderately that when a problem arises during the courses of the program, there will be an effort to solve this problem.

The answers given by the students to the item "The course materials and tests offered on the portal are used in a way to strengthen the subject" are gathered around the "I neither agree nor disagree" option $(\bar{X}: 2,98)$. The fact that the average of the students' responses to the items which are about the numbers of materials and resources in input component is lower than the average of the responses to this item in the process component indicates that they think that the resources and materials offered are used effectively by the instructors even if they are not given enough resources and materials.

In addition, the students gave the answer of "I neither agree nor disagree" $(\bar{X}: 3,07)$ to the item "Exams are hold without problems". However, the average of the students' responses is over 3 and close to "I agree" option. Averages and standard deviation values of students' responses to the items in the product component of the curriculum were calculated and given in Table 7.

The answers given by the students to the item "At the end of the courses, the students have reached the intended level of English" are gathered around the "I neither agree nor disagree" option $(\bar{X}: 2,67)$. But the fact that average of the answers is so close to the "I do not agree" option is a remarkable finding. Therefore, the opinions of the students about the achievement of the desired level of English at the end of the courses are close to negative.

The answers to the questions $26,28,30,31,32,33$ and 34 , which are about whether the curriculum accomplished the objectives or not, are 2,80, 2,85, 2,71, 2,76, 2,70, 2,72 and 2,69 respectively. Among the items related to whether the objectives are accomplished or not, the item with the lowest average is about the speaking skill $(\overline{\mathrm{X}}: 2,69)$. Among the items about the resources and materials in the input component, the fact that the item with the lowest average is about the speaking skill $(\overline{\mathrm{X}}: 2,55)$ can be related to this finding in the product component. In addition, among the answers given by the students to the items related to the objectives, the items with the highest average are the 26th, 28th, 30th and 33th items which are about learning, remembering and using new vocabularies appropriately $(\bar{X}: 2,80, \bar{X}: 2,85$, 
$\overline{\mathrm{X}}: 2,71, \overline{\mathrm{X}}: 2,72)$. Besides that, the answers to the item "I think the curriculum has reached its objectives", which is asked to determine the general view on reaching the targets, are gathered around "I neither agree nor disagree" option ( $\overline{\mathrm{X}}: 2,83)$.

The average of the responses to "The curriculum has improved distance learning skills" is 2,81 . Therefore, it can be said that they do not agree this item. It is a remarkable finding that the averages of the responses to "I am glad to complete these courses" and "I think that this curriculum is beneficial to me" which aim to directly determine students' perspectives are 2,84 and 2,76. So, their answers are gathered around "I neither agree nor disagree" option about the satisfaction of completing the courses and the benefit of the curriculum. Besides, the answers to the item "The curriculum has increased the interest in English" are also gathered around "I neither agree nor disagree" option $(\overline{\mathrm{X}}: 2,71)$.

Table 7. Averages and standard deviation values of the students' responses to the items in product component of the curriculum

\begin{tabular}{|c|c|c|}
\hline Product Evaluation & $\overline{\mathrm{X}}$ & ss \\
\hline 24. At the end of the courses, the students have reached the intended level of English. & 2,67 & 1,18 \\
\hline 25. The curriculum has improved distance learning skills. & 2,81 & 1,18 \\
\hline 26. Curriculum has developed the vocabulary learning strategies. & 2,80 & 1,21 \\
\hline 27. I think the curriculum has reached its objectives. & 2,83 & 1,20 \\
\hline 28. Curriculum has improved the ability to guess the meaning of unknown words in the texts. & 2,85 & 1,17 \\
\hline 29. I am glad to complete these courses. & 2,84 & 1,23 \\
\hline 30. Curriculum has improved memorization strategies. & 2,71 & 1,19 \\
\hline 31. Curriculum has improved the ability to read and understand texts. & 2,76 & 1,18 \\
\hline $\begin{array}{l}\text { 32. At the end of the courses, the students have reached the level to express themselves by } \\
\text { writing in English. }\end{array}$ & 2,70 & 1,22 \\
\hline $\begin{array}{l}\text { 33. At the end of the courses, students have learned how to use appropriate vocabulary when } \\
\text { needed. }\end{array}$ & 2,72 & 1,16 \\
\hline 34. At the end of the courses, the students improved their ability to communicate in English. & 2,69 & 1,20 \\
\hline 35. The curriculum has increased the interest in English. & 2,71 & 1,21 \\
\hline 36. I think that this curriculum is beneficial to me & 2,76 & 1,22 \\
\hline Total & 2,76 & 0,96 \\
\hline
\end{tabular}

3.2 Findings on Whether the Opinions of the Students about Distance Education Curriculum of Foreign Language I Course Differ According to Different Variables or Not

In order to determine whether the students' opinions about the distance education curriculum of Foreign Language I course differ significantly according to their gender or not, independent samples $t$ test was performed and the results were given in Table 8.

Table 8. Examination of the students' opinions about the Foreign Language I curriculum according to gender variable

\begin{tabular}{lccccccc}
\hline & Gender & $\mathbf{n}$ & $\bar{X}$ & ss & t & p \\
\hline \multirow{2}{*}{ Students' Opinions About Curriculum } & Female & 474 & 2,79 & 0,79 & & \\
\cline { 2 - 7 } & Male & 241 & 2,91 & 0,88 & $-1,772$ & 0,077 \\
\hline
\end{tabular}

It was found out that there is not any significant difference between the opinions of male and female students $\left(t_{715}=-1,772, p>0,050\right)$. Therefore, gender is not a variable which affects students' views on the curriculum.

In order to determine whether the students' opinions about the distance education curriculum of Foreign Language I course differ significantly according to students' age or not, one way ANOVA test was performed and the results were given in Table 9.

It was found out that the difference between the opinions of students according to their age is not significant $\left(\mathrm{F}_{715}=\right.$ $1,673, \mathrm{p}>0,050)$. Therefore, the students' ages do not have a significant influence on their views on the distance education curriculum of Foreign Language I course. 
Table 9. Mean, standard deviation values and the results of one way ANOVA analysis of the students' views on the distance education curriculum according to age variable

\begin{tabular}{|c|c|c|c|c|c|c|c|}
\hline Age & $\mathbf{n}$ & $\mathrm{X}$ & SS & sd & $\mathbf{F}$ & $\mathbf{P}$ & Significant Difference \\
\hline 18 & 70 & 2,81 & 0,85 & & & & \\
\hline 19 & 157 & 2,80 & 0,82 & & & & \\
\hline 20 & 196 & 2,85 & 0,84 & & & & \\
\hline 21 & 138 & 2,91 & 0,83 & & & & \\
\hline 22 & 64 & 2,88 & 0,72 & $8 / 706$ & 1,673 & 0,102 & - \\
\hline 23 & 38 & 2,68 & 0,71 & & & & \\
\hline 24 & 23 & 2,53 & 0,87 & & & & \\
\hline 25 & 10 & 2.19 & 0,87 & & & & \\
\hline $26+$ & 19 & 3,03 & 0,86 & & & & \\
\hline
\end{tabular}

In order to determine whether the opinions of the students about the distance education curriculum of Foreign Language I course differ significantly according to types of education variable or not, independent samples t test was performed and the results were given in Table 10.

Table 10. Examination of the opinions of the students about the Foreign Language I curriculum according to types of education variable

\begin{tabular}{|c|c|c|c|c|c|c|c|c|}
\hline & & & Type of Education & $\mathbf{n}$ & $\overline{\mathrm{X}}$ & ss & $\mathbf{t}$ & $\mathbf{p}$ \\
\hline \multirow{2}{*}{$\begin{array}{l}\text { Students' } \\
\text { Curriculum }\end{array}$} & \multirow[t]{2}{*}{ Opinions } & \multirow[t]{2}{*}{ About } & Daytime Education & 557 & 2,80 & 0,85 & & \\
\hline & & & Evening Education & 158 & 2,93 & 0,71 & $-2,034$ & 0,043 \\
\hline
\end{tabular}

It was found out that there is a significant difference between the opinions of students who are enrolled in daytime education and evening education $\left(\mathrm{t}_{715}=-2,034, \mathrm{p}<0,05\right)$. Thus, type of education is a variable which affects students' views on the curriculum. When the students' averages are examined, it is seen that the average of the students enrolled in the evening education $(\bar{X}: 2,93)$ is higher than the average of the students enrolled in the daytime education $(\overline{\mathrm{X}}$ : 2,80 ). In other words, the students who are enrolled in evening education have more positive opinions about the curriculum of Foreign Language I course which is conducted with distance education than the students who are enrolled in daytime education. It can be though that one of the reasons of this is the feature of distance education which makes it possible for evening education students to follow the courses by online videos wherever or whenever they want instead of going to school.

In order to determine whether the opinions of the students about the distance education curriculum of Foreign Language I course differ significantly according to whether they have a personal computer or not, independent samples t test was performed and the results were given in Table 11.

Table 11. Examination of the opinions of the students about the Foreign Language I curriculum according to whether they have a personal computer or not

\begin{tabular}{lcccccc}
\hline & & $\mathbf{n}$ & $\bar{X}$ & ss & t & p \\
\hline \multirow{2}{*}{ Students' Opinions About Curriculum } & Have & 494 & 2,87 & 0,81 & & \\
\cline { 2 - 7 } & Don't Have & 221 & 2,73 & 0,85 & 2,150 & 0,032 \\
\hline
\end{tabular}

It was found out that there is a significant difference between the opinions of the students who have a personal computer and the students who do not have a personal computer $\left(t_{715}=2,150, p<0,050\right)$. It is seen that the average of the opinions of the students who have personal computers $(\bar{X}: 2,87)$ are higher than those who do not have personal computers $(\bar{X}$ : 2,73 ). It can be said that students who have personal computers are more advantageous than those who do not have to follow distance education courses whenever they want. It is seen that this advantage has positive effects on the students' opinions about the distance education curriculum. It can be said that students who do not have personal computers have to find a computer to follow the lessons or they have to follow lessons through smartphones and this adversely affect their views about the distance education curriculum.

In order to determine whether the opinions of the students about the distance education curriculum of Foreign Language I course differ significantly according to whether they have attended another distance education before or not, independent samples $t$ test was performed and the results were given in Table 12. 
Table 12. Examination of the opinions of the students about the Foreign Language I curriculum according to whether they have attended another distance education before or not

\begin{tabular}{lccccccc}
\hline & & $\mathbf{n}$ & $\bar{X}$ & ss & t & p \\
\hline \multirow{2}{*}{ Students' Opinions About Curriculum } & Yes & 182 & 2,95 & 0,75 & & \\
\cline { 2 - 7 } & No & 533 & 2,79 & 0,84 & 2,470 & 0,014 \\
\hline
\end{tabular}

It was found out that there is a significant difference between the opinions of the students who have attended another distance education before and those who do not have attended any other distance education before $\left(\mathrm{t}_{715}=2,470, \mathrm{p}<0,050\right)$. It can be seen that the average of the opinions of the students who have attended another distance education before $(\bar{X}$ : $2,95)$ are higher than those who do not have attended $(\bar{X}: 2,79)$. It can be seen as an important finding that the opinions of the students who have previously experienced a distance education are positive about this curriculum. The students who have not experienced any distance education before may have difficulties to understand how to use the distance education portals and to find out how to make use of distance education; and this may have negative impact on their views on the distance education curriculum.

In order to determine whether the opinions of the students about the distance education curriculum of Foreign Language I course differ significantly according to the hour they spend on internet or not, one way ANOVA test was performed and the results were given in Table 13.

Table 13. Mean, standard deviation values and the results of one way ANOVA analysis of the students' views on the distance education curriculum according to daily internet connection

\begin{tabular}{|c|c|c|c|c|c|c|c|}
\hline $\begin{array}{c}\text { Daily Internet } \\
\text { Connection }\end{array}$ & $\mathbf{n}$ & $\bar{X}$ & ss & sd & $\mathbf{F}$ & $\mathbf{P}$ & Significant Difference \\
\hline $0-2$ & 337 & 2,70 & 0,86 & \multirow{5}{*}{$4 / 710$} & \multirow{5}{*}{5,107} & \multirow{5}{*}{.000} & \multirow{5}{*}{$\begin{array}{l}E-A \\
B-A\end{array}$} \\
\hline $3-5$ & 264 & 2,92 & 0,75 & & & & \\
\hline 6-8 & 77 & 2,91 & 0,75 & & & & \\
\hline $9-11$ & 16 & 2,77 & 1,00 & & & & \\
\hline $12+$ & 21 & 3,34 & 0,83 & & & & \\
\hline A:0-2 & $\mathrm{B}: 3-5$ & \multicolumn{3}{|c|}{$C: 6-8$} & & $9-11$ & $\mathrm{E}: 12+$ \\
\hline
\end{tabular}

It was found out that the difference between the opinions of students according to the hour they spend is significant $\left(\mathrm{F}_{715}=5,107, \mathrm{p}<0,050\right)$. In order to check variance homogeneity, Levene test was performed and it was seen that variances are not homogeneous $(\mathrm{p}<0,050)$. So, Tamhane's $\mathrm{T} 2$ test, a multiple comparison test, was performed to determine the difference is between which averages and it was found out that the average of the students' opinions who spend more than 12 hours a day on the internet $(X: 3,34)$, is significantly higher than the average of the opinions of the students who spend between $0-2$ hours $(\bar{X}: 2,70)$. In addition, the average of the students' opinions who spend between 3-5 hours a day on the internet ( $\overline{\mathrm{X}}: 2,92)$, is significantly higher than the average of the opinions of the students who spend between $0-2$ hours $(\bar{X}: 2,70)$.

In order to determine whether the opinions of the students about the distance education curriculum of Foreign Language I course differ significantly according to their final grade or not, one way ANOVA test was performed and the results were given in Table 14.

Table 14. Mean, standard deviation values and the results of one way ANOVA analysis of the students' views on the distance education curriculum according to final grade variable

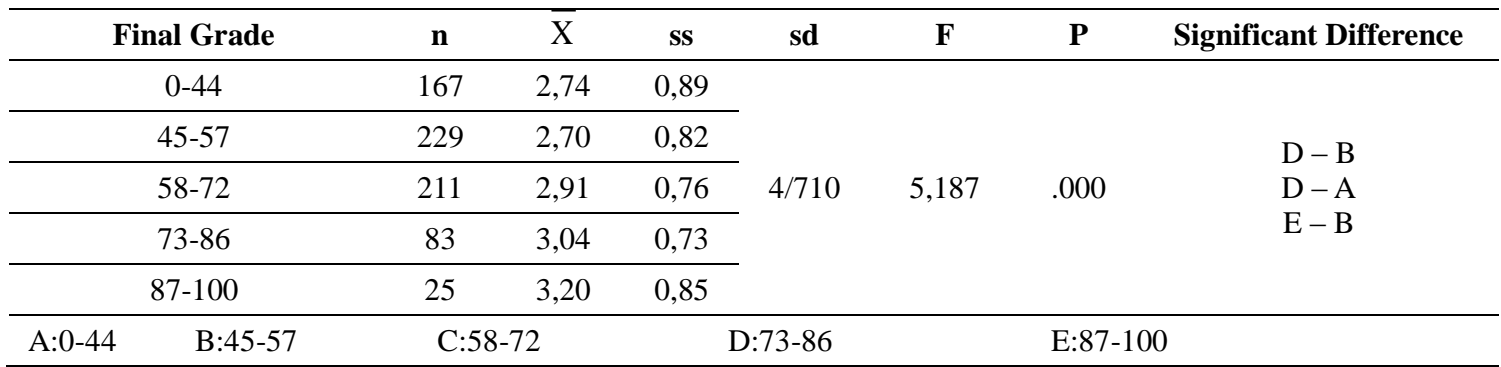

It was found out that the difference between the opinions of students according to their final grade is significant $\left(\mathrm{F}_{715}=5,187, \mathrm{p}<0,050\right)$. Due to the variances are homogenous $(\mathrm{p}>0,050)$, Tukey test, a multiple comparison test, was performed to determine which averages the difference is between and it was found out that the average of the opinions of the students whose final grades are between $73-86$ ( $\overline{\mathrm{X}}: 3,04)$, is significantly higher than the average of the opinions 
of the students whose final grades are between $45-57(\bar{X}: 2,70)$ and whose final grades are between $0-44(\bar{X}: 2,74)$. Besides that, the average of the opinions of the students whose final grades are between $87-100(\bar{X}: 3,20)$, is significantly higher than the average of the opinions of the students whose final grades are between 45-57 ( $\bar{X}: 2,70)$.

\section{Discussion}

\subsection{Discussions on the Students' Opinions about Distance Education Curriculum of Foreign Language I Course}

The average of the students' responses to the items about the distance education curriculum is "I neither agree nor disagree". The component which has the most positive opinions is the process component. The process component is followed by context and input components respectively. Besides that, the component which has the most negative opinions is product component.

Contrary to the findings of this study, Çakır and Yurtsever (2012) found out that the students have positive opinions about the distance education curriculum and the only problem emanates from technological infrastructure at the end of their study on distance education curriculum which was conducted in Karabük University. In addition, at the end of her study in which Cansu (2010) has evaluated technology applications in primary education e-certificate curriculum with CIPP model in Anadolu University, she reached the conclusion that the component which has the most positive opinions is product component. Besides, Cansu (2010) found out that students' opinions on distance education e-certificate curriculum are generally positive. In addition to that, Unal (2011), who has evaluated Erasmus student mobility program with CIPP model, has reached the conclusion that students have positive opinion about the program. Harrison et al. (2014) has evaluated the graduate curriculum which is conducted with distance education and has reached the conclusion that the opinions of the students about the curriculum are positive. Therefore, the studies mentioned above do not show parallelism with the results of this study, which reached the conclusion that opinions of the students are gathered around "I neither agree nor disagree" about the distance education curriculum of the Foreign Language I course.

The averages of the responses of the students to the items about the harmony of curriculum with their needs, expectations and levels are "I neither agree nor disagree". In addition, the students' opinions about the duration of courses and their relation with other courses are gathered around "I neither agree nor disagree" option. However, students think that this distance education curriculum of Foreign Language I course is not effective to improve English.

In his study conducted in Yıldız Technical University School of Foreign Languages, Karataş (2007) has reached the conclusion that the responses of the students about the suitability of the curriculum with the needs and expectations of the students, appeal of the course materials and sufficiency of the courses' duration are gathered around "I agree" and "I partly agree". Therefore, Karataş's conclusions do not show parallelism with the results of this study, which reached the conclusion that the opinions of the students about the harmony of curriculum with their needs, expectations and levels are at the level of "I neither agree nor disagree".

As a result of analyzing the answers given to the items related to the input component of the curriculum, it was found out students moderately agree with the idea of that they are provided enough resources about the listening, writing, reading and grammar skills. However, students think that they are not given enough resources about speaking skill. In addition, their responses to the quality of the materials provided to them are also gathered around "I neither agree nor disagree". Besides that they have close to positive opinion on the quality of the courses offered to them and the number of tests.

Similar to the results of this study, Karataş (2007) found out that visual and auditory materials facilitate the students' learning, have positive effects on their language skills, and that the students have a moderate level of satisfaction about their quality. In his study in which Ekmekçi (2015) has evaluated the foreign language curriculum conducted by distance education with the opinions of freshman students, he has reached the conclusion that there are not enough activities and materials about speaking skill. Alıc (2004) found out that the students have negative opinions about the materials and resources provided to them at the end of his study in which he aims to determine the quality of preparatory education by using only the opinions of the students. In addition, Tunç (2010) found out that while students are provided with enough resources related to the other skills of language, they are not provided with enough resources about speaking and listening skill at the end of his study in which he has evaluated English curriculum in a state university with CIPP evaluation model. Therefore, the results obtained from these studies support the results of this study.

As a result of analyzing the answers given to the items related to the process component of the curriculum, it has been reached the conclusion that the opinions of the students about the communicating with the lecturer easily, the lecturing of the instructors in the course videos, the effective usage of the materials are moderate. However, the average of student responses to the items related to these subjects is not far away from the "I agree" option. Students also have a 
positive opinion on whether the exams are implemented without problems during the curriculum. Students' responses to the item regarding the elimination of a disruption that occurs during the courses are gathered around "I neither agree nor disagree" option.

In parallel with the results of this study, in his study, Karataş (2007) found out that students have a positive opinion about the courses, assignments and the usage of materials. Contrary to the results of this study, Tokmak, Baturay and Fadde (2013) have reached the conclusion that most of the students think that instructors do not use the appropriate teaching method, they cannot make the course interesting and they cannot be reached when needed. Moreover, according to the results obtained by Tokmak, Baturay and Fadde (2013), students stated that they could not get help quickly to solve the problem when they encountered a problem during the courses.

After analyzing the students' responses to the items related to the product component of the curriculum, it is seen that the students have a negative opinion about reaching the intended level of English at the end of the curriculum. In addition, the students' answers given to the items about the achievement of the objectives about different skills of the language at the end of the curriculum are gathered around "I neither agree nor disagree" option. It is seen that among these skills, speaking skill has the lowest average. It has reached the conclusion that students have a moderate opinion on whether the curriculum has achieved its objectives or not. Besides, it is also found out that students' responses to the items about the satisfaction of completing the courses and the benefit of the curriculum are gathered around "I neither agree nor disagree" option.

In his study, Karataş (2007) found out that at the end of the curriculum, students have a moderate degree of satisfaction in contributing of the courses to the students in their other department courses and encouraging of the curriculum to learn English. Therefore, this result is in line with the results obtained at the end of this research. Furthermore, again in parallel with the results of this study, Karataş (2007) has reached to the point that the students are moderately satisfied with their progress in English reading, writing, listening, speaking skills and grammar knowledge at the end of the curriculum. Besides that, in his study in which Virlan (2014) has aimed to evaluate the curriculum of a speaking course in a state university with CIPP evaluation model, he found out that students cannot improve their speaking skills enough to follow their other department courses. Likewise Mersinligil (2002) evaluated the fourth and fifth grade English course curriculum and found out that while the students have partially positive opinions on the improvement of their reading, writing, speaking and listening skills, they have more positive opinions on the improvement of grammar. In addition, Vural (2004), Büyükduman (2005) and Tunç (2010) have reached the conclusion that English speaking skill cannot be adequately taught in their studies about the evaluating of English course curriculums at university and primary school levels. Therefore, it can be said that English speaking skill cannot be learned enough by the students regardless of the level of education.

As a result, the students' opinions on all components of the distance education curriculum of Foreign Language I course are gathered around "I neither agree nor disagree". Therefore, the curriculum needs to be strengthened in all components, especially in the product component.

\subsection{Discussions on Whether the Students' Opinions about Distance Education Curriculum of Foreign Language I Course Differ According to Different Variables or Not}

After analyzing the collected data to find the answer to the second question of the research, it was seen that the students' gender and age variables do not have any significant effects on the students' opinions on the distance education curriculum of Foreign Language I course.

In parallel with the results of this study, there are studies in the literature which show that gender (Tunç, 2010; Cansu, 2010; Unal, 2011) and age (Cansu, 2010) do not affect significantly the students' opinions on distance education.

Contrary to the results of this study, there are also studies in the literature which show that gender (Ozer, 2011) and age (Ozer, 2011; Tekinarslan, 2008) are variables which affect students' opinions on distance education.

Another result of the research is that the students who study in the evening education have more positive opinions than the students who study in the daytime education. This result can be explained by the feature of distance education which makes it possible for evening education students to follow the courses by online videos wherever or whenever they want instead of going to school.

It is seen that having a personal computer or not is also another variable which affects students' opinions on the distance education curriculum. The students who have a personal computer have more positive opinion on the curriculum. The students who have personal computers are more advantageous than those who do not have to follow distance education courses whenever they want. It is seen that this advantage has positive effects on the students' opinions about the distance education curriculum.

Also, it was found out that the students who have attended another distance education before have more positive 
opinions about distance education curriculum of Foreign Language I course than those who do not have attended. In parallel with the results of this study, Unal (2011) found out that the students who have experienced Erasmus student mobility program before have more positive opinions than the students who have not. Therefore, the result of this study, which says that the students who have experienced distance education before are more positive about distance education than those who have not experienced any distance education before, is supported by the studies in the literature.

After analyzing whether the students' daily internet connection hours significantly affect their opinions on the curriculum, it is concluded that this variable affects students' opinions. Students who spend more than 12 hours a day and 3-5 hours a day on the internet have more positive opinions than students who spend 0-2 hours a day on the internet. In parallel with this study, Eygü and Karaman (2013) have reached the conclusion that there is a significant relation between students' daily internet connection hours and their satisfaction levels about distance education. Therefore, it can be said that the result of this study is in parallel with the other studies in the literature.

Also, it was found out that the difference between the opinions of students according to their final grade is significant. The average of the opinions of the students whose final grade is more than 73 is significantly higher than the average of the opinions of the students whose final grade is less than 57 . Therefore, it can be said that students' final grades influence their opinions on the curriculum positively.

In conclusion, the average of the students' opinions on the distance education curriculum of Foreign Language I course is at the level of "I neither agree nor disagree". It was seen that opinions of the students about curriculum don't differ significantly according to their gender and age. However, opinions of the students differ significantly according to the faculties or colleges which they are enrolled, their type of education, whether or not they have a personal computer, whether or not they have attended distance education before, their daily internet connection hours and their final grade.

According to the results of this research, the following suggestions can be made for the implementing staff of the curriculum:

- The distance education curriculum of Foreign Language I course should be developed in every component and product component is the most important one to be developed.

- Extensive orientation training can be done to increase the distance learning and internet use competences of the students who will take the Foreign Language I course offered by distance education.

- Facilities which make it possible for the students who do not have personal computers to follow the courses easily on every campuses of the university.

According to the results of this research, the following suggestions can be made for the other researchers:

- Other studies may be conducted to investigate the effectiveness of distance education English language curriculums on different sample groups.

- Qualitative studies may be conducted to investigate the effectiveness of distance education English language curriculums.

- More extensive studies can be conducted by adding different stakeholders to sample, such as teaching staff and managers.

- Further studies may be conducted on whether gender and age are effective or ineffective on distance education curriculums.

\section{References}

Alıc1, S. S. (2004). The opinions of Ylldiz Technical University, foreign languages department English preparatory school students' on the quality of education they are provided with (Master Thesis). Y1ldiz Teknik University Social Sciences Institute, Istanbul. Retrived from https://tez.yok.gov.tr/UlusalTezMerkezi/

Bell, D. (1999). The coming of post-industrial society: A venture in social forecasting. New York: Basic Books.

Büyükduman, F. I. (2005). The Opinions of Elementary School English Teachers on the English Curriculum for Elementary Schools. Hacettepe University Journal of Education, 28, 55-64.

Büyüköztürk, Ş. (2002). Factor Analysis: Basic Concepts and Using to Development Scale. Educational Administration in Theory \& Practice, 32, 470-483.

Cansu, T. (2010). Evaluation of Anadolu University e-certificate program on technology applications in primary education with context, input, process, product (CIPP) model ant learner opinions (Master Thesis). Anadolu Üniversity Social Sciences Institute, Eskişehir. Retrived from https://tez.yok.gov.tr/UlusalTezMerkezi/

Çakır, G., \& Yurtsever, B. (2012). An implementation of distance education program for teaching common necessary courses in formal education: Karabük Univesity sample. Procedia-Social and Behavioral Sciences, 55, 187-195. 
https://doi.org/10.1016/j.sbspro.2012.09.493

Çallı, I., Işman, A., \& Torkul, O. (2001). Past, Present and Future of Distance Education at Sakarya University. Sakarya University Journal of Education Faculty, 3, 1-7.

Demir E. (2014). Overview of Distance Education. Dumlupinar University Journal of Social Sciences, 39, 1-1.

Ekmekçi, E. (2015). Distance education in foreign language teaching: evaluations from the perspectives of freshman students. Procedia-Social and Behavioral Sciences, 176, 390-397. https://doi.org/10.1016/j.sbspro.2015.01.487

Eygü, H., \& Karaman, S. (2013). A Study On The Satisfaction Perceptions Of The Distance Education Students. Klrkkkale Üniversitesi Sosyal Bilimler Dergisi, 3(1), 36-59.

Harrison, R., Gemmell, I., \& Reed, K. (2014). Student's satisfaction with a web-based dissertation course: Findings from an international distance learning master's programme in public health. The International Review Research in Open and Distance Learning, 15(1), 182-202.

Işman, A. (2008). Distance Education. Ankara: Pegem Akademi.

Karakaya, M., \& Aksoy, H. H. (2005). Distance Education Master Thesis Study. Ankara: Ankara University Faculty of Education.

Karataş, H. (2007). Evaluation of the syllabus of English II instruction program in modern languages department, Ylldlz Technical University via the opinions of the teachers and students using context, input, process and product (CIPP) model (Master Thesis). Yıldı Teknik University Social Sciences Institute, İstanbul. Retrived from https://tez.yok.gov.tr/UlusalTezMerkezi/

Mersinligil, G. (2002). Evaluation of the English language curriculum for the fourth and fifth grade students in elementary education: (A Sample of Adana province) (Doctoral Dissertation). Firat University Social Sciences Institute, Elazığ. Retrived from https://tez.yok.gov.tr/UlusalTezMerkezi/

Moore, M., \& Kearsley, G. (2005). Distance education: A systems view (2. Edition) Belmont: Wadsworth.

Ozer, B. (2011). Evaluation of distance education programs in terms of students and teaching staff wievs (Master Thesis). Abant Izzet Baysal University Educational Sciences Institute, Bolu. Retrived from https://tez.yok.gov.tr/UlusalTezMerkezi/

Simonson, M. (2002). In case you're asked: The effectiveness of distance education. The Quarterly Review of Distance Education, 3(4), 7-10.

Tekinarslan, E. (2008). Attitudes of Turkish Distance Learners Toward Internet-based Learning: An Investigation Depending On Demographical Characteristics. Turkish Online Journal of Distance Education-TOJDE, 9(1).

Tokmak, H. C., Baturay, H. M., \& Fadde, P. (2013). Applying the context, input, process and product evaluation model for evaluation, research and redesign of an online master's program. The International Review Research in Open and Distance Learning, 14(3), 273-293. https://doi.org/10.19173/irrodl.v14i3.1485

Tunç, F. (2010). Evaluation of an English Language Teaching Program at a public university using CIPP model (Master Thesis). Orta Doğu Teknik University Social Sciences Institute, Ankara. Retrived from https://tez.yok.gov.tr/UlusalTezMerkezi/

Unal, M. (2011). The evaluation of European Union Erasmus Student Mobility Programme in the framework of CIPP (context, input, process, product) evaluation model (Doctoral Dissertation). Gazi University Educational Sciences Institute Ankara. Retrived from https://tez.yok.gov.tr/UlusalTezMerkezi/

Virlan, A. Y. (2014). A case study: Evaluation of an English speaking skills course in a public university preparatory school program via CIPP model (Master Thesis). Yeditepe University Educational Sciences Institute, Istanbul. Retrived from https://tez.yok.gov.tr/UlusalTezMerkezi/

Vural, T. (2004). An evaluation of the curriculum applied at the Preparatory Engilish Classes of Ylldiz Technical University (Master Thesis). Yıldız Teknik University Social Sciences Institute, Istanbul. Retrived from https://tez.yok.gov.tr/UlusalTezMerkezi/

Webster, F. (2001). Theories of the information age (2. Edition). London: Routledge. https://doi.org/10.4324/9780203426265

Yadigar, G. (2010). The evaluation of the efficiency of distance education programs (Master Thesis). Gazi University Educational Sciences Institute, Ankara. Retrived from https://tez.yok.gov.tr/UlusalTezMerkezi/

\section{Copyrights}

Copyright for this article is retained by the author(s), with first publication rights granted to the journal.

This is an open-access article distributed under the terms and conditions of the Creative Commons Attribution license which permits unrestricted use, distribution, and reproduction in any medium, provided the original work is properly cited. 